\title{
Brazilian spotted fever serological survey among equids at the Guarapiranga Dam area in the city of São Paulo, Brazil
}

\author{
Investigação sorológica da febre maculosa brasileira entre equídeos na \\ área da represa de Guarapiranga, na cidade de São Paulo, Brasil
}

\author{
Amanda Sousa de Oliveira ${ }^{1}$, Tania Regina Vieira de Carvalho², Marcelo Bahia Labruna ${ }^{1}$, Jonas Moraes-Filho ${ }^{1,2}$ (D) \\ ${ }^{1}$ Universidade de São Paulo, Faculdade de Medicina Veterinária e Zootecnia, São Paulo - SP, Brazil \\ ${ }^{2}$ Universidade Santo Amaro, São Paulo - SP, Brazil
}

\begin{abstract}
In the Guarapiranga dam region located in the metropolitan area of São Paulo, human cases have been reported of Brazilian spotted fever (BSF), a tick-borne disease caused by the bacterium Rickettsia rickettsii. In this area, $R$. rickettsii is known to be transmitted to humans by Amblyomma aureolatum, a typical dog tick that is not associated with horses. In other BSF-endemic areas, $R$. rickettsii transmission is associated with Amblyomma sculptum, a tick species that typically infest capybaras and horses. The Guarapiranga Dam bears abundant populations of capybaras and horses. However, since nothing is known about a possible cycle of transmission of $R$. rickettsii by A. sculptum in this area, this study evaluated such transmission by performing a serosurvey of horses living in the Guarapiranga Dam region. A total of 206 equids living in the margins of the Guarapiranga Dam were serologically tested for antibodies reactive to five Rickettsia species, four of the spotted fever group ( $R$. rickettsii, $R$. parkeri, $R$. amblyommatis, $R$. rhipicephali) and one basal group species, $R$. bellii. Overall, 171 (83\%) equids reacted positively to at least one Rickettsia species. A total of 160 (78\%), 123 (60\%), 80 (39\%), 72 (35\%), and 71 (34\%), equid sera reacted to $R$. bellii, $R$. rickettsii, $R$. parkeri, $R$. rhipicephali, and $R$. amblyommatis, respectively, with endpoint titers ranging from 64 to 1024 for $R$. bellii, and 64 to 512 for the remaining four Rickettsia species. Endpoint titers to R. bellii (median: 256) was significantly higher $(P<0.05)$ than the endpoint titers to the other four Rickettsia species, for which the median values varied from 64 to 128. A total of 65 (32\%) equid sera showed endpoint titers to $R$. bellii at least 4 -fold higher than those to any of the other four antigens, indicating that they have been exposed to $R$. bellii or a very closely related species. Our results provide serological evidence that the sampled equids were not frequently exposed to $R$. rickettsii-infected ticks. Since horses are a highly suitable sentinel for $R$. rickettsii transmission by A. sculptum, we conclude that this tick species has no epidemiological role in the transmission of $R$. rickettsii in the BSF-endemic area of the Guarapiranga Dam in the metropolitan area of São Paulo.
\end{abstract}

Keywords: Rickettsia rickettsii. Rickettsia bellii. Immunofluorescence assay. Horse. Tick.

\section{RESUMO}

Na região da represa de Guarapiranga localizada na área metropolitana de São Paulo, têm sido relatados casos humanos de Febre Maculosa Brasileira (FMB), uma doença transmitida por carrapatos causada pela bactéria Rickettsia rickettsii. Nesta área de estudo, $R$. rickettsii é conhecida por ser transmitida aos seres humanos pelo Amblyomma aureolatum, um carrapato de cão que não está associado a cavalos. Em outras áreas endêmicas da FMB, a transmissão de $R$. rickettsii está associada ao Amblyomma sculptum, uma espécie de carrapato que normalmente infesta capivaras e cavalos. A represa de Guarapiranga possui populações abundantes de capivaras e cavalos; no entanto, como nada se sabe sobre um possível ciclo de transmissão de $R$. rickettsii por $A$. sculptum nessa área, este estudo avaliou essa transmissão realizando um levantamento sorológico em cavalos que vivem na região da represa de Guarapiranga. Um total de 206 equídeos que vivem nas margens da represa de Guarapiranga foram testados sorologicamente para cinco espécies de Rickettsia, sendo quatro do grupo da FMB (R. rickettsii, $R$. parkeri, R. amblyommatis, R. rhipicephali) e um do grupo basal ( $R$. bellii). No geral, 171 (83\%) equídeos reagiram positivamente a pelo menos uma espécie de Rickettsia. Um total de 160 (78\%), 123 (60\%), 80 (39\%), 72 (35\%) e 71 (34\%), reagiram a $R$. bellii, $R$. rickettsii, $R$. parkeri, $R$. rhipicephali e $R$. amblyommatis, respectivamente, com títulos finais variando de 64 a 1024 para $R$. bellii e 64 a 512 para as quatro espécies restantes de Rickettsia. Os títulos finais para R. bellii (mediana: 256) foram significativamente maiores $(\mathrm{P}<0,05)$ do que os títulos para as outras quatro espécies de Rickettsia, para os quais os valores medianos variaram de 64 a 128. Um total de 65 (32\%) equideos, os soros mostraram títulos finais para $R$. bellii pelo menos quatro vezes maior que os de qualquer um dos 
outros quatro antígenos, indicando que eles foram expostos a $R$. bellii ou a uma espécie muito próxima. Os resultados obtidos fornecem evidências sorológicas de que os equídeos amostrados não eram frequentemente expostos a carrapatos infectados por $R$. rickettsii. Como os cavalos são um sentinela altamente adequado para a transmissão de $R$. rickettsii por A. sculptum, a conclusão obtida foi que essa espécie de carrapato não tem papel epidemiológico na transmissão da bactéria na área endêmica de FMB da represa de Guarapiranga na região metropolitana de São Paulo.

Palavras-chave: Rickettsia rickettsii. Rickettsia bellii. Teste de imunofluorescência. Cavalo. Carrapato.

Correspondence to:

Jonas Moraes Filho

Universidade Santo Amaro

Rua Professor Enéas de Siqueira Neto, 340, Jardim das Imbuias

CEP: 04829-300, São Paulo - SP, Brasil

e-mail: jmfilho@prof.unisa.br

Received: June 02, 2019

Approved: September 20, 2019
How to cite: Oliveira AS, Carvalho TRV, Labruna MB, Moraes-Filho J. Brazilian spotted fever serological survey among equids at the Guarapiranga Dam area in the city of São Paulo, Brazil. Braz J Vet Res Anim Sci. 2019;56(4): e158601. https://doi.org/10.11606/issn.1678-4456.bjvras.2019.158601

\section{Introduction}

Brazilian spotted fever (BSF), also known as Rocky Mountain spotted fever (RMSF) in the United States, is an anthropozoonosis restricted to the America mainland, caused by the bacterium Rickettsia rickettsii. In Brazil, $R$. rickettsii is transmitted to humans chiefly by two tick species, Amblyomma sculptum and Amblyomma aureolatum (Chen \& Sexton, 2008; Guedes et al., 2005; Labruna et al., 2011; Labruna, 2009; Parola et al., 2013; Pinter \& Labruna, 2006; Pinter et al., 2011).

Most of the BSF cases in Brazil are associated with the tick A. sculptum (formerly Amblyomma cajennense in southeastern Brazil), whose $R$. rickettsii-infected populations are sustained mainly by capybaras (Hydrochoerus hydrochaeris), and horses (Equus caballus) in a lesser extent (Labruna et al., 2002; Vieira et al., 2004). While R. rickettsii undergoes transovarial transmission in ticks (McDade \& Newhouse, 1986), $R$. rickettsii elicits some deleterious effect on ticks. Hence, the maintenance of the natural cycle of the bacterium for successive tick generations depends on horizontal transmission via infected vertebrate hosts (e.g., capybaras), in order to create new cohorts of infected ticks (Labruna et al., 2011; Soares et al., 2012).

In BSF-endemic areas, horses might play an important role because they are primary hosts of A. sculptum, and after being exposed to a $R$. rickettsii-infected tick, they develop an effective humoral response that is usually detectable for many months through regular serological tests (Ueno et al., 2016). For this reason, horses can be used as suitable sentinels for BSF in southeastern Brazil (Sangioni et al., 2005). It is important to note that horses do not develop bacteremia to infect susceptible ticks. Therefore, they play no direct role in the maintenance of $R$. rickettsii in nature (Ueno et al., 2016).

BSF has long been described as a disease of transmission in rural and wild areas. However, peri-urban and urban areas have been presenting cases in humans, mainly related to the density of humans residing in small fragments of remaining forests (Ogrzewalska et al., 2012; Souza et al., 2015). The State of São Paulo has the highest incidence of BSF cases in humans in the country, where A. sculptum is the main vector of the disease in the countryside. On the other hand, in the metropolitan region of São Paulo City, an unique transmission cycle of $R$. rickettsii involves another tick species, Amblyomma aureolatum (Horta et al., 2007; Ogrzewalska et al., 2012), which uses Passeridae birds and small rodents for immature stages (larvae and nymphs), and wild carnivores and domestic dogs (Canis familiaris) for adult ticks (Arzua et al., 2003; Fonseca, 1935; Ogrzewalska et al., 2012). Since horses are not natural hosts for A. aureolatum (Horta et al., 2007; Ogrzewalska et al., 2012), they are not considered to be suitable sentinels for BSF in these areas where $R$. rickettsii is transmitted by A. aureolatum.

Recent cases of BSF in the metropolitan area of São Paulo near Guarapiranga and Billings dams were investigated, and the presence of A. sculptum and A. aureolatum ticks were recorded through acarological surveys. Infection by $R$. rickettsii was detected in A. aureolatum ticks, plus positive canine seropositivity to $R$. rickettsii, supporting a transmission cycle by A. aureolatum (Coordenadoria de Controle de Doenças, 2014). On the other hand, the Guarapiranga Dam bears abundant populations of capybaras and several locations with horses. Since nothing is known about a possible cycle of transmission of $R$. rickettsii by A. sculptum in this area, this study evaluated such transmission by performing a serosurvey of horses living in the Guarapiranga Dam area, where recent cases of BSF have been reported. 


\section{Material and Methods}

\section{The Guarapiranga Dam}

The Guarapiranga Dam is supplied by a basin that receives the same name, by the rivers Capivari, Monos and Taquecetuba (stream linking the Billings Reservoir). Its extension is of approximately $630 \mathrm{~km}^{2}$, partially occupying lands of different cities of the São Paulo metropolitan area, namely Embu-Guaçu, Itapecerica da Serra, São Lourenço da Serra, Juquitiba, Embu and São Paulo. Nearly 800,000 inhabitants are estimated to live on its banks and $60 \%$ of them are residents in the city of São Paulo (Companhia de Saneamento Básico do Estado de São Paulo, 2008).

\section{Horse blood collection}

This study was been approved by the Institutional Animal Care and Use Committee (IACUC) of the Faculty of Veterinary Medicine of the University of São Paulo (protocol No. 4329041116). After previous authorization by horses' owners, $5 \mathrm{ml}$ of blood samples were collected in clean and dry glass tubes through a puncture of the jugular vein using the vacutainer system. Samples were identified according the animal number, properties, species and gender, and were later stored in isothermal boxes filled with ice and taken to the laboratory, where samples were centrifuged at $12.000 \mathrm{~g}$ for $10 \mathrm{~min}$ to separate the blood serum that were aliquoted in microtubes and cryopreserved at $-20^{\circ} \mathrm{C}$ until serological analysis.

\section{Indirect Immunofluorescence Assay (IFA)}

Horse sera were tested by IFA against antigens of fie Rickettsia species, for belonging to the spotted fever group, $R$. rickettsii (strain Taiaçu), $R$. parkeri (strain At24), R. amblyommatis (strain Ac37), and R. rhipicephali (strain HJ\#5), and a fifth species, R. bellii (strain Mogi), which belongs to the basal group of the genus Rickettsia. Reactions were performed as previously described (Horta et al., 2004). Known positive and negative control sera from the study of Ueno et al. (2016) were used in each slide. Horse sera were initially diluted in 1:64 of PBS (0.1 M, pH7.2) and applied upon slides previously sensitized with the antigens, and then incubated in humid chamber at $37^{\circ} \mathrm{C}$ for $30 \mathrm{~min}$. The slides were then washed twice with PBS and dried at environmental temperature. After drying, a goat anti-horse IgG fluorescein isothiocyanate conjugate (Sigma, St Louis, MO, USA) was applied at the dilution of 1:1200 of PBS to the slides, which were incubated in humid chamber at $37^{\circ} \mathrm{C}$ for $30 \mathrm{~min}$. After that, the slides were washed twice with PBS containing 0.02\% Evans blue and dried at environmental temperature. Dried slides were mounted with glass coverslips over buffered glycerin solution and read in an ultraviolet microscope at the 40x objective (Olympus, Tokyo, Japan). Sera with reactivity at the 1:64 dilution were titrated at 2-fold increments to the endpoint titer to each of the rickettsial antigens. Serum showing for a Rickettsia species titer at least 4-fold higher than that observed for any other Rickettsia species was considered homologous to the first Rickettsia species or a very closely related species (Horta et al., 2004; Ueno et al., 2016).

\section{Statistical analyses}

Equid endpoint titers to the five Rickettsia species were compared by the non-parametric Mann-Whitney test.

\section{Results}

Samples of 206 resident equids (188 horses, 13 mules, 3 mini horses, and 2 ponies) from the margins of the Guarapiranga Dam were collected from eight private properties, where the animals were used for leisure, local work (mini-farm show, horse riding, equine therapy), pilgrimages and sports competitions. Among the animals collected, $24.3 \%$ were females and $75.7 \%$ males.

Of the 206 equids tested by IFA, 171 (83\%) reacted positively to at least one Rickettsia species. A total of 160 (78\%), 123 (60\%), 80 (39\%), 72 (35\%), and 71 (34\%), equid sera reacted to $R$. bellii, $R$. rickettsii, $R$. parkeri, $R$. rhipicephali, and $R$. amblyommatis, respectively, with endpoint titers ranging from 64 to 1024 for $R$. bellii, and 64 to 512 for the remaining four Rickettsia species. Only eight animals reacted with another Rickettsia species without reacting with $R$. bellii. Endpoint titers to R. bellii (median: 256) was significantly higher $(P<0.05)$ than the endpoint titers to the other four Rickettsia species, for which the median values varied from 64 to 128 (Figure 1).

A total of 65 (32\%) equid sera showed endpoint titers to $R$. bellii at least 4-fold higher than those to any of the other four antigens. The antibody titers in these 65 equids were considered to have been stimulated by $R$. bellii or a very closely related species. Based on this criterion, a single serum was considered to have been stimulated by $R$. rickettsii or a closely related species. For the remaining equids, it was not possible to discriminate the infection agent, because they displayed similar titers ( $<4$-fold difference) for two or more Rickettsia species or had a single titer of 64 for a single Rickettsia species. 


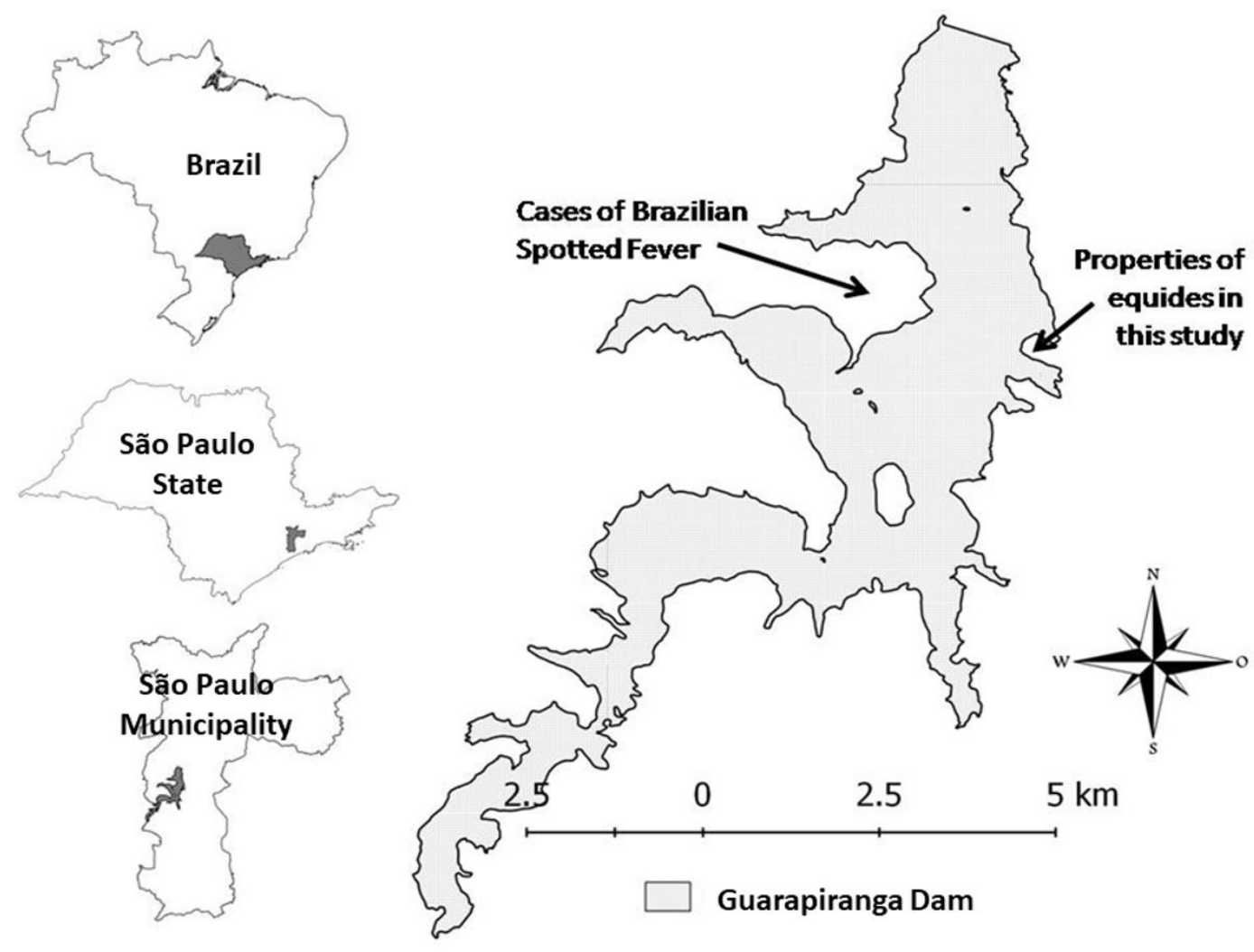

Figure 1. Boxplot representing the serological endpoint titers for five Rickettsia species of equids from the Guarapiranga Dam in Brazil. Different lower case letters mean statistically different $(P<0.05)$ endpoint titers between Rickettsia species.

\section{Discussion}

We tested a sample of 206 equids for seroreactivity to five Rickettsia species, which included four of the spotted fever group ( $R$. rickettsii, $R$. parkeri, $R$. amblyommatis, $R$. rhipicephali) and one basal group species, $R$. bellii. The obtained results indicated that most of the seropositive horses displayed highest endpoint titers to R. bellii. Hence, most of the seroreactivity to spotted fever group species were probably cross-reactions, indicating that these horses had not been exposed to spotted fever group agents. The only exception was a single horse that had an endpoint titer 4-fold higher for $R$. rickettsii than for the remaining four Rickettsia species. This single horse might have been exposed to a $R$. rickettsii-infected tick. However, this unique finding among a sample of 206 sampled horses excluded the participation of A. sculptum in the transmission of $R$. rickettsii in the Guarapiranga Dam area, where horses have been frequently infested by A. sculptum (data not shown). This statement is supported by previous studies in other BSF-endemic areas in São Paulo state, where R. rickettsii is transmitted by A. sculptum and most of the seropositive horses had highest titers to $R$. rickettsii (Horta et al., 2004; Vianna et al., 2008). Moreover, it is possible that this single horse with highest titer to $R$. rickettsii might have been infested by a $R$. rickettsii-infected $A$. aureolatum tick, since this tick species, while not a common parasite of horses (Guglielmone et al., 2003), has been found with a $\approx 10 \%$ R. rickettsii-infection rate in the metropolitan area of São Paulo municipality (Ogrzewalska et al., 2012).

A high number of equids presented serological evidence of exposure to R. bellii or a closely related agent. Indeed, $R$. bellii has been reported as the most common Rickettsia species infecting ticks in Brazil (Krawczak et al., 2018; Labruna et al., 2011). However, it is not a common agent that infects typical ticks of horses, namely A. sculptum and Dermacentor nitens (Labruna et al., 2011). Since R. bellii represents a rickettsial basal group that includes a variety of closely related agents infecting leeches, insects, protozoa, or even plants (Murray et al., 2016; Weinert et al., 2009), we did not exclude the possibility that any of these other organisms could be related to the $R$. bellii high seropositivity in the present study, a condition yet to be investigated.

The BSF-confirmed cases on the margins of the Guarapiranga Dam have been concentrated in a single region (indicated in Figure 2). When these cases occurred, an epidemiological survey was carried out in the area by official Health Organs, when blood samples were collected from dogs, cats and horses. While horses were seronegative to $R$. rickettsii, dogs and cats were found to have highest antibody titers to $R$. rickettsii, and this agent was also identified 


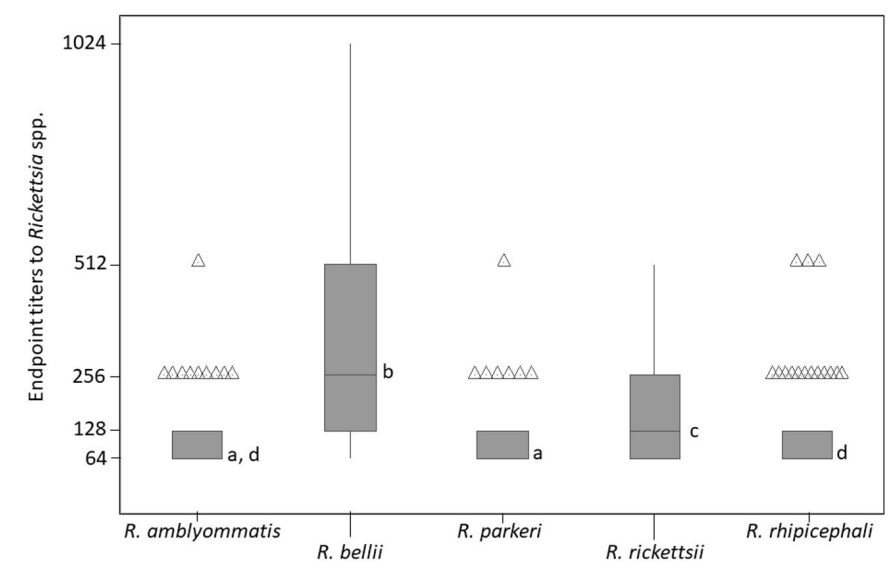

Figure 2. Location of the equid properties sampled in the present study among the margins of the Guarapiranga Dam in the Municipality of São Paulo, Brazil.

by polymerase chain reaction (PCR) in A. aureolatum ticks parasitizing the sampled dogs (CCD, 2014). The equids examined in the present study used to graze on properties in the margins of the Guarapiranga Dam. During flood periods, wild animals, mainly capybaras, approached these properties to feed on grass lands(unpublished data). In addition, many of these equids circulate throughout the Guarapiranga Dam margins on routine tours. Our results provide serological evidence that these horses are not frequently exposed to $R$. rickettsii-infected ticks. Since horses

\section{References}

Arzua M, Silva MAN, Famadas KM, Beati L, Barros-Battesti DM. Amblyomma Aureolatum and Ixodes Auritulus (Acari: Ixodidae) on Birds in Southern Brazil, with Notes on Their Ecology. Exp Appl Acarol. 2003;31(3-4):283-96. http://dx.doi.org/10.1023/B:APPA.0000010381.24903.1c. PMid:14974693.

Chen LF, Sexton DJ. What's new in rocky mountain spotted fever? Infect Dis Clin North Am. 2008;22(3):415-32, vii-viii. http://dx.doi.org/10.1016/j.idc.2008.03.008. PMid:18755382.

Companhia de Saneamento Básico do Estado de São Paulo - SABESP. Dossiê - Sistema Guarapiranga. São Paulo: SABESP; 2008.

Coordenadoria de Controle de Doenças - CCD. Boletim Epidemiológico Paulista - BEPA. 2014;11(129):1-37.

Fonseca F. Validade da especie e cyclo evolutivo de Amblyomma striatum KOCH, 1844 (Acarina, Ixodidae). Mem Inst Oswaldo Cruz. 1935;9:43-58. are a highly suitable sentinel for $R$. rickettsii transmission by A. sculptum (Sangioni et al., 2005), the obtained conclusion is that this tick species has no epidemiological role in the transmission of $R$. rickettsii in the BSF-endemic area of the Guarapiranga Dam in the metropolitan area of São Paulo municipality. However, since the epidemiology of BSF is dynamic, serosurveys on horses should be routinely employed in the study area to detect any epidemiological significant change.

\section{Conflict of Interest}

The authors state that they have no conflicts of interest to declare.

\section{Ethics Statement}

This study was been approved by the Institutional Animal Care and Use Committee (IACUC) of the Faculty of Veterinary Medicine of the University of São Paulo (protocol No. 4329041116).

\section{Acknowledgements}

Thanks to the National Council for Scientific and Technological Development (CNPq), the Foundation for Research Support of the State of São Paulo (FAPESP) (process 2016/00167-0), for the financial support to carry out the scientific study.

Guedes E, Leite RC, Prata MCA, Pacheco RC, Walker $\mathrm{DH}$, Labruna MB. Detection of Rickettsia rickettsii in the tick Amblyomma cajennense in a new Brazilian spotted fever-endemic area in the state of Minas Gerais. Mem Inst Oswaldo Cruz. 2005;100(8):841-5. http://dx.doi.org/10.1590/ S0074-02762005000800004. PMid:16444414.

Guglielmone AA, Estrada-Peña A, Mangold AJ, BarrosBattesti DM, Labruna MB, Martins JR, Venzal JM, Arzua M, Keirans JE. Amblyomma aureolatum (Pallas, 1772) and Amblyomma ovale Koch, 1844 (Acari: Ixodidae): hosts, distribution and 16S rDNA sequences. Vet Parasitol. 2003;113(3-4):273-88.

Horta MC, Labruna MB, Pinter A, Linardi PM, Schumaker TTS. Rickettsia Infection in Five Areas of the State of Sao Paulo, Brazil. Mem Inst Oswaldo Cruz. 2007;102(7):793801. http://dx.doi.org/10.1590/S0074-02762007000700003. PMid:18094887.

Horta MC, Labruna MB, Sangioni LA, Vianna MCB, Gennari SM, Galvão MAM, Mafra CL, Vidotto O, Schumaker TTS, 
Walker DH. Prevalence of antibodies to spotted fever group Rickettsiae in humans and domestic animals in a Brazilian spotted fever-endemic area in the state of São Paulo, Brazil: serologic evidence for infection by Rickettsia rickettsii and another spotted. Am J Trop Med Hyg. 2004;71(1):93-7. http://dx.doi.org/10.4269/ ajtmh.2004.71.93. PMid:15238696.

Krawczak FS, Labruna MB, Hecht JA, Paddock CD, Karpathy SE. Genotypic characterization of Rickettsia bellii reveals distinct lineages in the United States and South America. BioMed Res Int. 2018;2018:1-8. http:// dx.doi.org/10.1155/2018/8505483. PMid:29850579.

Labruna MB, Kasai N, Ferreira F, Faccini JLH, Gennari SM. Seasonal dynamics of ticks (Acari: Ixodidae) on horses in the state of São Paulo, Brazil. Vet Parasitol. 2002;105(1):65-77. http://dx.doi.org/10.1016/S03044017(01)00649-5. PMid:11879967.

Labruna MB, Ogrzewalska M, Soares JF, Martins TF, Soares HS, Moraes-Filho J, Nieri-Bastos FA, Almeida AP, Pinter A. Experimental Infection of Amblyomma aureolatum Ticks with rickettsia rickettsii. Emerg Infect Dis. 2011;17(5):829-34. http://dx.doi.org/10.3201/ eid1705.101524. PMid:21529391.

Labruna MB. Ecology of rickettsia in South America. Ann N Y Acad Sci. 2009;1166(1):156-66. http://dx.doi. org/10.1111/j.1749-6632.2009.04516.x. PMid:19538276.

McDade JE, Newhouse VF. Natural history of Rickettsia rickettsii. Ann Rev Microbiol. 1986;40:287-309.

Murray GGR, Weinert LA, Rhule EL, Welch JJ. The Phylogeny of Rickettsia using different evolutionary signatures: how tree-like is bacterial evolution? Syst Biol. 2016;65(2):265-79. http://dx.doi.org/10.1093/ sysbio/syv084. PMid:26559010.

Ogrzewalska M, Saraiva DG, Moraes-Filho J, Martins TF, Costa FB, Pinter A, Labruna MB. Epidemiology of Brazilian spotted fever in the Atlantic Forest, State of São Paulo, Brazil. Parasitology. 2012;139(10):1283300. http://dx.doi.org/10.1017/S0031182012000546. PMid:22716923.

Parola P, Paddock CD, Socolovschi C, Labruna MB, Mediannikov O, Kernif T, Abdad MY, Stenos J, Bitam I, Fournier PE, Raoult D. Update on tick-borne rickettsioses around the world: a geographic approach. Clin Microbiol Rev. 2013;26(4):657-702. http://dx.doi.org/10.1128/ CMR.00032-13. PMid:24092850.
Pinter A, França AC, Souza CE, Sabbo C, Nascimento EMM, Santos FCP, Katz G, Labruna BM, Holcman MM, Alves MJCP, Horta MC, Mascheretti M, Mayo RC, Angerami RN, Brasil RA, Leite RM, Aparecida SS, Souza L, Colombo S, Oliveira VLM. Febre maculosa brasileira. Suplemento Bepa. 2011;8(1):32-51.

Pinter A, Labruna MB. Isolation of Rickettsia rickettsii and Rickettsia bellii in cell culture from the tick Amblyomma aureolatum in Brazil. Ann N Y Acad Sci. 2006;1078(1):523-9. http://dx.doi.org/10.1196/ annals.1374.103. PMid:17114770.

Sangioni LA, Horta MC, Vianna MC, Gennari SM, Soares RM, Galvão MA, Schumaker TT, Ferreira F, Vidotto O, Labruna MB. Rickettsial infection in animals and Brasilian spotted fever endemicity. Emerg Infect Dis. 2005;11(2):265-70. http://dx.doi.org/10.3201/ eid1102.040656. PMid:15752445.

Soares JF, Soares HS, Barbieri AM, Labruna MB. Experimental infection of the tick Amblyomma cajennense, Cayenne tick, with Rickettsia rickettsii, the agent of Rocky Mountain spotted fever. Med Vet Entomol. 2012;26(2):139-51. http://dx.doi.org/10.1111/j.13652915.2011.00982.x. PMid:22007869.

Souza CE, Pinter A, Donalisio MR. Risk factors associated with the transmissionof Brazilian spotted fever in the Piracicaba river basin, State of São Paulo, Brazil. Rev Soc Bras Med Trop. 2015;48(1):11-17.

Ueno TEH, Costa FB, Moraes-Filho J, Agostinho WC, Fernandes WR, Labruna MB. Experimental infection of horses with Rickettsia Rickettsii. Parasit Vectors. 2016;9(1):499. http://dx.doi.org/10.1186/s13071-0161784-y. PMid:27624315.

Vianna MC, Horta MC, Sangioni LA, Cortez A, Soares RM, Mafra CL, Galvão MA, Labruna MB, Gennari SM. Rickettsial spotted fever in Capoeirão village, Itabira, Minas Gerais, Brazil. Rev Inst Med Trop São Paulo. 2008;50(5):297-301. http://dx.doi.org/10.1590/S003646652008000500009 . PMid:18949349.

Vieira A, Souza C, Labruna M, Mayo R, Souza S, Camargo-Neves V. Manual de vigilância acarológica. São Paulo: Secretaria de Estado da Saúde; 2004. p. 1-63.

Weinert LA, Werren JH, Aebi A, Stone GN, Jiggins FM. Evolution and diversity of Rickettsia bacteria. BMC Biol. 2009;7(1):1-15. http://dx.doi.org/10.1186/17417007-7-6. PMid:19187530. 
Financial Support: The scientific research was funded by FAPESP (São Paulo State Research Support Foundation), with case number 2016/00167-0.

Authors Contributions: Amanda Sousa de Oliveira: collection of animal samples, performance of serological and molecular tests of the collected samples, analysis of the results found, elaboration of the scientific text. Realization of serological and molecular tests of the collected samples, analysis of the results found, elaboration of the scientific text. Tânia Regina Vieira de Carvalho: realization of serological tests of the collected samples, analysis of the results found, elaboration of the scientific text. Conducting serological tests of the collected samples, analysis of the results found, elaboration of the scientific text. Marcelo Bahia Labruna: assistance in carrying out serological tests, analysis of results and elaboration of the scientific text. Jonas Moraes-Filho: conducting serological tests of the collected samples, analysis of the results found, elaboration of the scientific text, responsible for the scientific project and obtaining financial resources. 